\title{
Lovak billogozása Mongóliában és Magyarországon
}

\section{Bevezetés}

A jószágjegy a tulajdonjegyek nagy csoportjába tartozik, legalapvetőbb szerepe, hogy kifejezze egy természetes vagy jogi személy, illetve közösség birtoklási igényét egy nagyobb értéket képviselő tárgy vagy élőlény, jelen esetben egy vagy több jószággal kapcsolatban. Maga a jegy olyan adatokat közöl, amelyek mélyebb összefüggéseket tárnak fel a jószág és a tulajdonos történeti, társadalmi és gazdasági hátteréről. A jegyek formavilága utal az adott kultúra szellemi műveltségének különböző rétegeire, előfordulnak köztük archaikus motívumok, írásjegyek karakterei, elvont fogalmakat megjelenítő ábrák, mágikus tartalmakkal rendelkező vallási szimbólumok.

A magyarországi billogozást először tudományos részletességgel feldolgozó Tárkány Szűcs Ernő cikkén kívül ${ }^{1}$ Paládi-Kovács Attila mủveiben, ${ }^{2}$ valamint Szenti Tibor és Bicsérdy Gyula könyvében ${ }^{3}$ kapunk áttekintést a billogok használatáról, történeti elterjedéséről, változatairól és megítéléséröl. Tárkány tanulmánya alapján további szócikkeket is írt a témában. ${ }^{4}$

Nemzetközi tudományos téren X. Perlē Mongol tümn̄̄ garlīg tamgār xaī̌ sudlax $n i$ címủ mủve számít alapvető forrásnak. ${ }^{5}$ A tulajdonjegyek társadalmi és kulturális jelentőségét Caroline W. Humphrey szocioantropológiai megközelítésủ tanulmányában mutatja be. ${ }^{6}$ A magyarországi mongolisták - Birtalan Ágnes ${ }^{7}$ és Ladjánszky Endre - terepen gyüjtött adataikkal járultak hozzá a tárgykör bővítéséhez. Ladjánszky mesterszakos szakdolgozatában

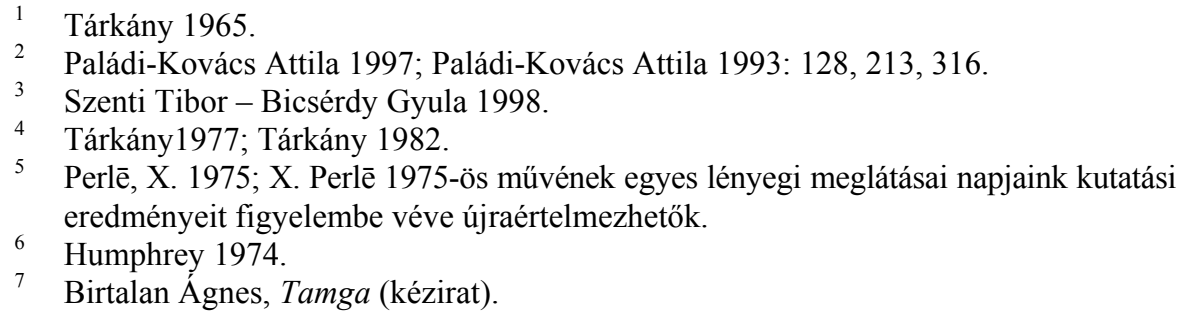


- amely egy korábbi cikkének kibővített változata $-{ }^{8}$ a mongol háziállatok, az ötfélejószág (tawan xošū mal) égetett jelöléseinek körülményeit jegyzi le, és röviden kitér a füljegyekre is. ${ }^{9}$ A téma további ismeretéhez S. Badamxatan és G. Cerenxand mongol kutatók háromkötetes néprajzi munkája, ${ }^{10}$ valamint D. Bayanbat 2016-os Mongol adūnī newterxī toli címü könyve ajánlott. ${ }^{11}$

A rendelkezésre álló adatokat saját terepmunka-eredményeimmel egészítem ki, amelyeket 2014-ben és 2017-ben közép- és keletmongol területeken gyüjtöttem. ${ }^{12}$ Ebből a 2017-es kutatóút meghatározó, ugyanis ekkor a passzív megfigyelésen és a képi dokumentáción kívül interjúkat is készítettem a billogozást végző lótulajdonos (X. Pürewxū) közremüködésével. ${ }^{13} \mathrm{Az}$ itt publikált eredményeimet korábban mesterszakos szakdolgozatomban közöltem, ezért a tanulmány a szakdolgozat bélyegezést tárgyaló fejezetének a kibővített változatát képezi. ${ }^{14}$

A mongol és a magyar kultúra a „népek országútjának” két végén helyezkedik el. A Magyarországhoz közel eső dobrudzsai és krími török és tatár sírok billogjairól publikált egy tanulmányt Baski Imre, ${ }^{15}$ a közép-ázsiai kazakok hagyományos lovas műveltségéröl - azon belül a billogozásról is - pedig Kun Péter írt átfogó, részletes könyvet. ${ }^{16} \mathrm{E}$ népek bélyegei között előfordulnak mindenhol ('́gy Magyarországon és Mongóliában is) felbukkanó alakzatok, amelyek valamilyen kapcsolatra engednek következtetni a nemzetségek és a törzsek között végig a sztyeppén, jelen tanulmány azonban nem kívánja e kérdéskört részletesebben tárgyalni. E tekintetben további kutatások szükségesek.

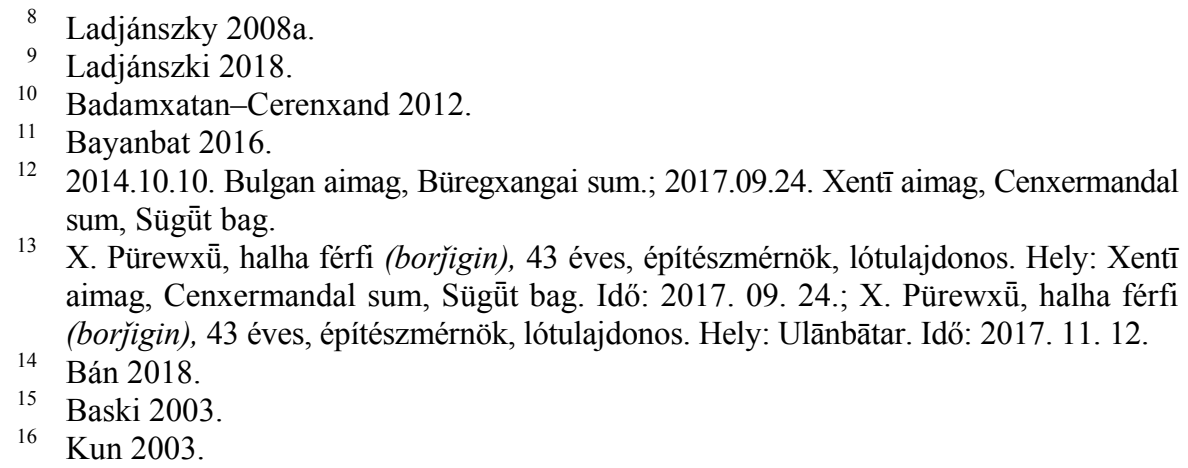

13 X. Pürewxü̈, halha férfi (borjigin), 43 éves, építészmérnök, lótulajdonos. Hely: Xentī aimag, Cenxermandal sum, Sügüt bag. Idő: 2017. 09. 24.; X. Pürewxü, halha férfi (borǰigin), 43 éves, építészmérnök, lótulajdonos. Hely: Ulānbātar. Idő: 2017. 11. 12.

14 Bán 2018.

15 Baski 2003.

16 Kun 2003. 


\section{Jószágjegyek tipológiája}

Az állat azonosítására a természetes és mesterséges jegyek összessége szolgál. ${ }^{17}$ Természetes jegynek számít minden olyan jellegzetesség, amely meghatározza az állat külsejét: a neme, a kora, a szőrszíne, a kiállása, a testhibái. Magyarországon a lovak azonosításának egyik ilyen módja (a különböző foltokon, hókán, zoknin/harisnyán kívül) a szőrforgóik számontartása. ${ }^{18}$ Mind a magyar, mind a mongol pásztorok gazdag szókinccsel rendelkeznek állataik körülírását illetően, ${ }^{19}$ ez azonban önmagában nem biztosítja a pontos meghatározást, hiszen a jószág alkata folyamatosan változik. ${ }^{20}$

A mongol és a magyar müveltség körében ma is ismert a füljegy (im) és a bélyeg (tamga). ${ }^{21}$ A füljegyet leginkább a kistestű lábasjószágon alkalmazták, ${ }^{22}$ a bélyeget pedig a távoli legelőre menő - a mongolok émikus megközelítése alapján - „hosszabb lábú” (xöl urttai) állatra sütötték. ${ }^{23}$ Ezenkívül használtak orrbemetszést a mongol területeken a nagylábas jószágnál, jelöltek festékkel (Magyarországon szurokkal is), ${ }^{24}$ mintákat vágtak az állat hosszúszőrébe, és címkét erősítettek a jószág farkára. ${ }^{25}$ A magyarságnál tetovált, karcolt vagy krétával felvitt jegyekről is beszélhetünk. ${ }^{26}$ Tárkány említi a bárányjelet is, amely egy fából faragott figura volt, amely az anyajuh nyakában függött, míg ennek kicsinyített mása báránya nyakára került, és a néprajzkutató elmondása alapján az volt a célja, hogy az anya megszokja kicsinyét. ${ }^{27} \mathrm{~A}$ technika fejlődésével a lovak jelölésében további újítások mentek végbe, Magyarországon használatos eljárás a fagyasztásos bélyegzés, ${ }^{28}$ a felső

17 Régen, ha egy állat eltűnt, a természetes és mesterséges jeleket leírva jelentették be a hatóságoknak (Tárkány 1965: 194).

18 Szajkó et al. 2009.

19 A mongol pásztorok jószággal kapcsolatos kifejezéseiről lásd: Avar 2008; Birtalan 2008.

20 Tárkány 1965: 193.

21 Tárkány 1977: 687.

22 Magyarországon a füljegyet és a bélyeget együtt is alkalmazták (Tárkány 1977: 687).

23 Magyar példa: Szabadfalvi 1977: 249; Mongol példa: Bayanbat 2016: 196.

24 Tárkány 1977: 688.

25 Ladjánszky 2008a: 2.

26 Tárkány 1965: 193, 385.

27 Tárkány 1977: 688; véleményem szerint a bárányjel inkább a pásztornak segített az azonosításban.

28 A bélyegzővasat hevítés helyett folyékony nitrogénben vagy szárazjégben hütik, így hömérséklete $-196{ }^{\circ} \mathrm{C}$-ra (nitrogén esetében) vagy $-78^{\circ} \mathrm{C}$-ra (szárazjég esetében) 
ínyre való tetoválás, a mikrochippelés és a szarugesztenye ${ }^{29}$ lenyomatának dokumentálása (lefényképezése). ${ }^{30}$ Tapasztalataim alapján ezek közül Mongóliában inkább a fagyasztásos bélyegzés (xüiten tamga) terjedt el, de nem kizárható, hogy a többi jelölés is létezik. A továbbiakban a hagyományos billogról és a fagyasztásról lesz szó.

\section{A billog fogalma}

A bélyeg fogalmának jogi részét az előző fejezetben már említettem. Meghatározásához olyan további szempontok is hozzátartoznak, mint hogy az ábra érzékileg felfogható, technikailag kivitelezhető legyen, és hogy alkalmazását a társadalom vagy legalább a helyi közösség elismerje. ${ }^{31}$ Ezen szempontokat figyelembe véve elmondható, hogy a billog égetéssel (vagy fagyasztással) az állat testére helyezett, olvasható vagy felismerhető ábrát tartalmazó minta. A magyar néprajzkutatók véleménye alapján a bélyeg szó (más formáiban billog, bellág, billyog, ${ }^{32}$ XVI. századi tájszólások nyomán billeg, billyeg, belleg, billyeg, bijeg, bélyog, béjog, béjjog, bélyok, bilyag, bélyag, bílig) ${ }^{33}$ származását nézve ótörök eredetü, és a baskírok, kirgizek, tatárok és mongolok körében (lásd beleg, beleg temdeg, kl. mong. belge alakban 'jel', 'jelkép', 'szimbólum') is elterjedt. ${ }^{34}$ Ebből a források arra következtetnek, hogy ezt a technikát eleink a honfoglalás előtt is alkalmazták. ${ }^{35}$ Írásos formában (bylegh) pedig elöször a XV. században bukkan fel. ${ }^{36}$ A magyar nyelv történeti-etimológiai szótára szerint a billog nem a bélyeg alakváltozata. Az ómagyar bilüküs szóból (ez a bélyeg ómagyar -s képzős származéka) kialakult hazai latin bilochus 'bíró' kifejezésből elvonással, annak alaki hatására fejlődött ki. ${ }^{37}$

\footnotetext{
csökken. Ezt a hideg vasat nyomják az állat leborotvált börére. A fagyasztás helyén újra kinővő szőr fehér lesz. (Lásd: Függelék: III. a, b, c kép).

29 A ló ötödik lábujjának elszarusodott maradványa a lábon.

30 Szajkó et al. 2009.

31 Ladjánszki 2018: 10; Tárkány 1965: 192-193; Tárkány 1982: 361.

32 Tárkány 1977: 687.

33 Tárkány 1965: 391.

34 Paládi-Kovács 2001: 635; Szabadfalvi 1977: 250.

35 Szabadfalvi 1977: 250; Paládi Kovács: 2001: 635.

36 Tárkány 1965: 196; Tárkány 1982: 362; Szabadfalvi 1977: 250.

37 Kiss-Papp 1984: 277.
} 
Szükségesnek tartom megjegyezni, hogy kutatásaim során nem tapasztaltam a beleg, beleg temdeg szavakat 'tulajdonjegy' értelemben használni. A mongol alakok jelentése, ahogyan fent leírtam, a 'jel' egy elvontabb, szimbolikus jelentésére utalnak, ezért nem állítható párhuzamba a magyar 'bélyeg', azaz 'tulajdonjegy' kifejezéssel. Ugyanez vonatkozik a török alakokra is. Gerard Clauson és Gerhard Dörfer müveikben nem tárgyalják a belgü 'jel', illetve bīlgä 'bölcs' szavak jelentésének 'tulajdonjegy' változatát. Clauson hangsúlyozza, hogy a belgüt 'absztrakt jelként', 'megkülönböztető jelként' kell értelmezni. ${ }^{38}$ A mongol nyelvekben a tamga (kl. mong. tama $-a$ ) 'jegy, tulajdonjegy' török eredetủ kifejezést használják. ${ }^{39}$ Ladjánszky szerint a tamgát először 'pecsét' jelentéssel vették át a mongolok, csak aztán szorította ki a feltételezhetően már létező másik, bélyegre vonatkozó szót. ${ }^{40}$

Napjainkban függetlenül attól, hogy Magyarországon milyen típusú állattenyésztő gazdálkodás zajlik, a billogozás elterjedt módszernek számít. Bár a bélyeg használata a XIII. századtól datálható, ${ }^{41}$ Tárkány összegzéséből kiderül, hogy a történelmi Magyarország azon területein maradt fenn több emlék, ahol az úgynevezett ázsiai eredetü, extenzív forma, a ridegtartás jellemezte a vidéket (például az Alföldön). ${ }^{42}$ Belső-Ázsia tájain mindig is a nomadizálás dominált, ezért az égetett jószágjelölés sokkal elterjedtebb jelenség volt, és hagyománya jóval a mongol kor előttre nyúlik vissza. A legkorábbi, bélyegjegyeket tartalmazó lelet egy Rašānxad nevű szikla, amely az őskőkorból származik, és Mongólia északi részén, Xentī megyében található. ${ }^{43}$ A sztyeppei legelőkön ritka az emberalkotta építmény, így az állat őrzése fontos és folyamatos feladatnak számított és számít a mai napig. A nyílt terepen rendszeresen előfordul, hogy néhány jószág elszakad és elveszik a többitől, vagy ellopják. Ilyen esetekben a tulajdonjegy megléte az egyetlen olyan eszköz, amellyel a pásztor bizonyíthatja a tulajdonjogát.

A bélyeg jelentéstartalma függ a tulajdonostól, az állat státuszától (például hogy a gazda ménesében született, vagy utólag vették), a mintától, és attól,

\footnotetext{
38 Dörfer 1965: 418-420; Clauson 1972: 340.

39 Clauson 1972: 504-505; Dörfer 1965: 554-565.

40 Ladjánszki 2018: 4. n. 6; Birtalan Tamga.

41 Tárkány 1982: 362; Szabadfalvi 1977: 250.

42 Tárkány 1965: 378.

43 Ladjánszki 2018: 4; Cewēndoř̄, 1999:71.
} 
milyen a felépítése, és hol helyezkedik el a jószág testén. A továbbiakban ezen szempontok alapján kívánom bemutatni, milyen eltérések vannak Magyarország és Mongólia között.

\section{A billog tulajdonlása, mennyisége és elhelyezése}

Magyarországon a kibocsátó lehet egy személy (a tulajdonos vagy az őrző), egy közigazgatási egység (a XVI-XVII. században némely törvényhatóság, város, község, földesúri birtok kötelezővé tette a bélyeghasználatot a területein tartott jószágon) $)^{44}$ vagy egy tenyésztelep, tenyésztőegyesület, ${ }^{45}$ esetleg egy kereskedelmi vagy ipari vállalkozás, akár maga a katonaság. ${ }^{46}$

A történelem során a jószágon egyszerre több bélyeg is előfordulhatott, forrásaim nem ismertettek azonban olyan magyar szokást, amelynek alapján a ló egyes testrészei megkülönböztetett, tiszteletbeli szerepet kaptak volna (ellentétben a mongol hagyománnyal, lásd lentebb). Tárkány állítása szerint a magyarok általában a jószág bal oldalára sütöttek, majd a XVIII. századtól rögzült a tulajdonjel bal oldalra, a területi jel (lásd alább) jobb oldalra való égetése, ennek azonban forrásaim nem tulajdonítottak rituális jelentőséget. ${ }^{47}$

Ismertek voltak a pásztorbélyegek, amelyeket az állat őrzésével megbízott pásztor sütött a jószágra, ha hosszabb időre került a gondozása alá. ${ }^{48} \mathrm{~A}$ tulajdonos titkos jegyet is égetett a jószágára a pontosabb azonosítás érdekében - lovak esetében ezt gyakran a sörény alá helyezték. ${ }^{49}$ Ha a jószág gazdát váltott, és rendelkezett már egy bélyeggel, a következő személy az állat egy másik testrészére helyezte a saját billogját, vagy egy másik fajta jelölést (például füljegyet) alkalmazott. Ilyenkor a két jelölés együttesen alkotta az új gazda jegyét az adott állaton, amelyet a papírokon is feltüntettek. ${ }^{50} \mathrm{~A}$ XXI. században az alábbi billogok találhatók meg egy magyar lovon: a fajtajel, a születési szám utolsó két számjegye, a megyejel és a csikószám. ${ }^{51}$

\footnotetext{
44 Tárkány 1965: 197.

45 Szajkó et al. 2009.

46 Tárkány 1965: 388.

47 Tárkány 1965: 386.

48 Tárkány 1965: 392.

49 Tárkány 1965: 392.

50 Tárkány 1965: 390.

51 A csikószám azt jelenti, hogy adott évben a bizonyos megyében hányadikként bélyegezték meg a csikót (Szajkó et al. 2009).
} 
A bélyegek állam vagy legalább intézmény általi ellenőrzése fokozatosan épült ki Magyarországon. Ahogy fentebb megjegyeztem, egyes közigazgatási egységek már a XVI. századtól szorgalmazták az égetett jószágjelölést, 1794-től azonban a Helytartótanács rendelte el a jószágok községenként való összeírását és a területi jelrendszer bevezetését. ${ }^{52}$ Voltak helységek, ahol a kovács volt a „nyilvántartó”, ugyanis megőrizte az általa készített bélyegzővasak nyomatait, és ismerte azok tulajdonosait. ${ }^{53}$ Egy új jel bevezetéséhez nem kellett külön hatósági engedélyt kérni, elég volt a helyi közösség elismerése és jóváhagyása. Ez és a bélyegzővas birtoklása elég alapot adott ahhoz, hogy bírósági, vitás kérdésekben a személy bizonyíthassa a tulajdonjogát. ${ }^{54}$

Mongóliában a billogtulajdonlás joga sokáig egy magánszemély társadalmi státuszától függött, majd a XX. században a szocialista kollektivizálás nyomán a termelőszövetkezet végezte a sütést. ${ }^{55}$ Ezenkívül szokásjog alapján az égetés helye is meg volt szabva a jószágon, az elit a jobb oldalra helyezte a bélyegét, a közemberek pedig a bal oldalra. ${ }^{56} \mathrm{~A}$ XXI. századra a bal oldali sütés vált elterjedtebbé, és a mongolok a ló ezen felét nevezik „helyes oldalnak” (jöw tal) ${ }^{57}$ Bayanbat állítása szerint a mongolok az úgynevezett „,napjárásnak megfelelő fordulás" szokását (nar jöw ergex yos) tisztelik ebben a hagyományban. ${ }^{58} \mathrm{Az}$ író további elmondása alapján a ló far- és combrészén (tašă, guya) kívül nem lehet más testtájra billogozni, mert a ló jószerencsével megáldott teremtmény (xīmorlog), ${ }^{59}$ és a máshova égetett billog csak elrontja a fenségét (sür jăwxāa, sür jawxalan). ${ }^{60} \mathrm{~A}$ bal oldali sütés Magyarországon is szinte kizá-

\footnotetext{
52 Tárkány 1965: 199.

53 Tárkány 1965: 388.

54 Tárkány 1965: 388.

55 Ladjánszki 2018: 12.

56 Humphrey 1974: 478; Ladjánszki 2018: 11.

57 Adatközlő: X. Pürewxü̈, halha férfi (borǰigin), 43 éves, építészmérnök, lótulajdonos.

58 Bayanbat 2016: 204.

59 A xīmorī tibeti eredetű szó, amelynek jelentése 'lelkierő', 'jószerencse', szó szerinti fordítása 'szélló', és eredetileg a tibeti buddhizmusból származó imazászlót jelentette (tib. rlung rta). Napjainkban a fogalom összefonódott a lovak alakjával, és úgy tartják, a nagy ménes vagy más, e jószágoktól származó vagy rájuk emlékeztető tárgy szerencsét és sikert hoz az embernek (Bán 2018: 9-10).

60

Bayanbat 2016: 204; Bán 2018: 16.
} 
rólagos jelenségnek számítottt, ${ }^{61}$ de a lovakat nyakon (fül mögött, sörény alatt), faron, combon, nyereghelyen vagy akár orron is billogozhatták. ${ }^{62}$

A szocializmus elött a legszegényebbek nem használtak bélyeget, és a „szolgáló státuszú” emberek is csak uruk billogját égették a jószágaikra, viszont az úr által használt testrésztől eltérő testtájra (feltehetőleg a ló bal combjára vagy farrészére) süthettek. Mint fentebb említettem, a közemberek az állat bal oldalát használták. A dzsingiszidák leszármazottai, a tajdzsik (taij, 'herceg', kl. mong. tayiji) más társadalmi rétegekétől eltérő, egységes billogjelet használtak. ${ }^{63}$ Mongóliában a buddhista kolostorokhoz földek és állatok is tartoztak (šabinar rendszer), amelyeket a tehetősebb világiak ajándékoztak nekik, hogy erényt gyüjtsenek, ${ }^{64}$ így a szerzetesek is használtak billogot. Humphrey szerint a napjainkban ismert, bélyegként alkalmazott vallási tartalmú formulák az ő tamgáik voltak. ${ }^{65} \mathrm{~A}$ ló adás-vételekor, ha eladását fiatal korában elöre eltervezték, ideiglenes bélyeget sütöttek a jószágra, ${ }^{66}$ de előfordultak olyan esetek is, amikor egy állandó jeggyel rendelkező jószágot bocsátottak piacra. Ilyenkor az állat újrabélyegezhető volt, ${ }^{67}$ viszont ha egy jelölt lovat ajándékba adtak, nem sütötték rájuk az új gazda tulajdonjegyét. ${ }^{68}$

Humphrey szerint - közli Ladjánszky - a XVIII-XIX. században törvény ${ }^{69}$ szabályozta új billog kibocsátását, illetve a jelölt jószágok mennyiségét. Egy új billog bevezetése felől elsősorban a helyi közösség, a nemzetség döntött, másodsorban a közeli kolostor lámái felügyelték és engedélyezték. Ha a kezdeményezést elfogadták, a jelet annak a zászlónak (kl. mong. qosirun) a hercege vette nyilvántartásba, amelyik alá az új jeltulajdonos tartozott. ${ }^{70}$ Ezenkívül a ménes minden tíz lovából csak egy viselhetett billogot (hasonló szabályozást mondtak ki tevékre is). Ez az intézkedés azzal magyarázható, hogy az állam-

61 Tárkány 1965: 386.

62 Tárkány cikkében a 387. oldalon összefoglalja az általános értelemben vett jószágjelölési helyeket, csupán néhol tér ki a lovakra (Tárkány 1965: 385, 387, 391); Szajkó István et al. 2009.

63 Ladjánszky 2018: 11.

64 Humphrey 1974: 477.

65 Humphrey 1974: 483.

66 Humphrey 1974: 478; Ladjánszki 2018: 14.

67 Humphrey 1974: 480.

68 Humphrey 1974: 480.

69 Humphrey tanulmányában a törvényi szabályozásokat részletezve nem jelöli meg, melyik törvénykönyvre hivatkozik, egyik esetben azonban Žamcarano 1959-es Qalq-a J̌irum' Halha Törvénykönyv’ című müvét említi. (Humphrey 1974: 480).

70 Humphrey 1974: 479; Ladjánszki 2018: 11. 
nak és a tajdzsiknak joga volt ideiglenesen igénybe venni a társadalmi rangban alattuk elhelyezkedő személyek jószágait, jelölt állatokat azonban nem alkalmazhattak különböző szolgálatokra (például futárszolgálatra). ${ }^{71}$

\section{A billog funkciói}

Az előző fejezetben leírt szempontok első felének ismertetése után a továbbiakban arról lesz szó, milyen különbségek figyelhetők meg a bélyeg jelentésváltozataiban Magyarországon és Mongóliában. Az itt közölt magyar billogfajták a jószágokra általánosan használt jegyek. A magyar források nem említenek külön lovakra égetett bélyegeket, csupán egyéb tulajdonjelölési módok esetén utaltak kizárólag lovaknál használt eljárásokra (például török és tatár hatás eredményeként a ló orrának behasítása). ${ }^{72}$ A mongol kultúrában többnyire lovakat, alkalmanként tevéket bélyegeztek. ${ }^{73}$ Tárkány rendszere alapján a magyar billogfajták a következők:

\section{Elvont fogalmakat jelentő ábrák}

a) Kereszt

b) $\mathrm{Kör}^{74}$

c) Daruláb ${ }^{75}$

Mủvelődéstörténeti szempontból

i. A természet világából származó billogok (csillag, tulipán, szív)

ii. A társadalom köréből származó billogok (emberalak)

iii. Megkülönböztető jegyek (császári korona, családi címerek, gyári jegyek)

iv. Mezőgazdasági eszközök (olló, sarló, patkó, kerék, villa)

v. Ipari eszközök (reszelö, mérleg)

vi. Egyéb ábrák (vasmacska, szélmalom, kalap, szemüveg)

71 Humphrey 1974: 480; Ladjánszki 2018: 11; Žamcarano 1959.

72 Paládi-Kovács 2001: 635.

73 Humphrey 1974: 478.

74 A motívum eredete túlnyúlik a magyar müveltségen, Tárkány megjegyzi, hogy a keleti és az északi népeknél a nap jelképeként szerepel (Tárkány 1965: 394).

75 Világszerte ismert és elterjedt jegyről van szó, „háromláb” néven Szophoklész egyik darabjában is előfordul, de felbukkan az irokéz müveltségben és a cserkeszek lovakra égetett billogai között is. A mongol kultúrát illetően XV. századi káni érméket is találtak ezzel a jellel (Tárkány 1965: 396). 


\section{Betük}

a) Egybetüs

b) Kétbetüs

c) Monogram ${ }^{76}$

d) Több-betüs

Írásfajta szerint:

i. Latin

ii. Gót

iii. Cirill

iv. Héber

v. Görög

\section{Számjegyek}

\section{A fentiek kombinációi ${ }^{77}$}

Ladjánszky rendszere alapján a mongol billogok a következők: ${ }^{78}$

\section{A mongol anyagi kultúra tárgyi világát megidéző billogok}

a) 'Íj és nyilas' billogfajták (num suman tamganī töröl)

b) 'Kalapácsos' billogfajták (alxan tamganī töröl)

c) 'Zablás' (jüjai); vagy 'horgos', illetve 'kampós' (degrēn tamganī töröl) billogfajták

d) 'Nehezékes', illetve 'mérlegsúlyos' (tūxain); vagy 'keresztes' (tōnolǰin tamganī töröl) billogfajták

\section{A természet jelenségeit megjelenítő billogfajták}

a) Élőlényekről elnevezett billogfajták (an amitnī nerēr nerlesen tamgan̄̄ töröl)

b) Emberi és állati testrészekről, szervekről elnevezett billogfajták (xün ba malīn erxtnēr nerlesen tamganī töröl)

c) Növényrészekröl elnevezett billogfajták (urgamlīn jüilēr nerlesen tamganī töröl)

76 Ha a két betü össze van füzve, monogramnak tekinthető (Tárkány 1965: 399).

77 Tárkány 1965: 392-399.

78 A felsorolás igen részletes, ezét a teljesség igénye nélkül a legfontosabbakat emelem ki. 


\section{Grafémákat és szóképeket megjelenítő billogok}

a) Tibeti betűs billogfajták (töwd üsgīn tamganī töröl)

b) Ujgur-mongol betüs billogfajták (uigarjin mongol üsgīn tamganī töröl)

c) Cirill betüs billogfajták (kirill üsgīn tamganī töröl)

d) Asztrológiainak vagy mennyiségtaninak nevezett (régi) számábrázolásos billogfajták (jurxain tōn tamganī töröl)

e) Arab (modern) számábrázolásos billogfajták (arabīn tōn tamganī töröl)

\section{Szimbólumokat és geometrikus formákat megjelenítő billogok}

a) Háromszög alakú (gurwalǰin vagy gurwan xošūn tamganī töröl); vagy 'tanvédö' (čoiǰin, čoinǰin, čoinjon vagy čoindon tamganī töröl); vagy 'fegyveres' (būn tamganī töröl); vagy doromnak nevezett (dormon tamganī töröl) billogfajták

b) Négyszög alakú billogfajták (dörwölǰin tamganī töröl)

c) 'Holdas' billogfajták (saran tamganī töröl)

d) Népi díszítőmotívumokat ábrázoló billogfajták (ündesn̄̄ xē ugaljn̄̄ tamganī töröl) $)^{79}$

Baski alapján tatár sírokban talált bélyegek feltételezett fejlődési lépcsőfokai a következők: ${ }^{80}$

1. Egyszerű formák, totemállatokat utánzó alakok

2. Háztartási eszközöket utánzó formák

3. Módosított jelek (kiegészítve vagy két különböző jegy egymás mellett)

Magyarországon a bélyegeket elsődlegesen adminisztratív, jogi célokra és - a fajtajel révén - tenyésztési nyilvántartásra használják. Létezik az égetett jószágjegyeknek egy elenyésző hányada a XXI. század előttről, amelyek bár nem sorolhatók a fenti szempontok alapján külön billogfajtába, funkciójukat nézve eltérő csoportba tartoznak, ezek Tárkány megfogalmazásában a beszélő jegyeket. Az akasztófa alakú jegy figyelmeztette az esetleges tolvajt, hogy ez a halálnem vár rá, ha lopáson érik. A magyarországi szász községek gyakran használtak olyan jegyeket, amelyekben „szerepelt” a falu neve, például a kakas alakú jegy Hahnbach (Kakasfalva) vagy a sertés formájú jegy Porcsesd bélyege volt. ${ }^{81}$

\footnotetext{
79 Ladjánszki 2018: 22-49.

80 Baski 2003: 44 46. Más kontextusban Tárkány is utal a bélyegek figurális fejlődésére, lásd: Tárkány 1965: 398.

81 Tárkány 1965: 398.
} 
A mongol kultúrában a billogoknak az adminisztratív funkciójuk mellett rituális jelentőségük is volt. A háziállatoknak, különösen a lovaknak bizonyos fokú természetfeletti erőt tulajdonítottak. ${ }^{82}$ Humphrey azt állítja, hogy a mongol világnézet szerint a ménes evilági és mágikus központja a mén volt, továbbá a csődör színének a lótulajdonossal való viszonya meghatározta az állomány gyarapodását. Minden mongol férfinak a gyermekkori hajvágó ünnepe után egy láma elárulja a neki rendelt védőistenséget, személynevet ${ }^{83}$ és lószínt, amelyek szerencsét hoznak neki. Minden színnek megfeleltethető egy tamga, és ha a gazda, a lószín és a billog ,párban állt”, a jószág védve volt a világi és természetfeletti ártalmaktól. Ha a ménes csökkent, a lovak betegeskedtek, pásztorok úgy gondolták, hogy a bélyeg nem illik a méneshez, ezért a lámákhoz fordultak, hogy megkaphassák a helyes jegyet. A burját mongolokról tudható, hogy áldozatot is bemutattak a bélyegnek. ${ }^{84} \mathrm{~A}$ billog védelmi szerepét az is erősítette, hogy az ábrák között szerepeltek vallási, néphitbeli, elvont jelentéstartalmú tamgák, például a halak jegy jelentése az „éberség” volt, vele elkerülhették a vadállatok támadását, boldogságfonat (öljī) az ,örökkévalóságot" ábrázolta, és viselőinek hosszú életet nyújtott. ${ }^{85}$

\section{A billog felépítése és ennek vonatkozásai}

Az égetett jószágtulajdonjegy a magyar és a mongol kultúrában is több elemre osztható, egy elsődleges és egy kisegítő vagy kiegészítő jelre. Az előző fejezetekben említett példákból láthattuk, hogy egy magyar ló testére több billog is kerülhet, sőt az eladott, bélyegzett jószágot az új és a régi gazda bélyegével együtt tartják nyilván. Tárkány leírja, hogy a Helytartótanács által kötelezővé tett területi vagy községjelet és a tulajdonos jegyét együttesen nevezték bélyegnek, azaz a területi vagy községjelek a billog részét képezik. ${ }^{86}$ Fontos kiemelni, hogy az ilyen jelek magukban is teljes értékü, önálló jegyekként is érvényesek, míg Mongóliában a kiegészítő jel az elsődleges jelhez képest alapvetően alárendelt viszonyban van. Megfigyeléseim alapján napjainkban a mongol lovakra összesen egy jegyet sütnek.

\footnotetext{
82 Bán 2018: 8-10.

83 Más források szerint a mongoloknál nem létezik névadási szokás a hajvágó ünnepekhez köthető rítusok között. A kérdés további kutatásokat igényel.

84 Humphrey 1974: 479.

85 Humphrey 1974: 479.

86 Tárkány 1965: 376.
} 
A mongol népek Dzsingisz kán uralkodása idejéig (1206-1226) nemzetségi, törzsi alapon szerveződtek, majd a Nagy Mongol Birodalom (1206-1368), a Jüan-dinasztiát követő Ming-dinasztia (1368-1644), valamint az azt legyőző Mandzsu Birodalom (1644-1912) az elfoglalt mongol területeken zászlókat (xošūn, kl. mong. qosirun) hozott létre, katonai egységekbe rendezte a lakosságot. ${ }^{87}$ Humphrey szerint a nomád társadalmak gazdasági központja mindig az állattartás volt, általában két-három család együtt legeltette a nyájait, méneseit, és az ilyen szerveződést örxnek ${ }^{88}$ nevezték. Az egymással vérségi kötelékben álló örxök egy törölt ('rokonság', kl. mong. törel) alkottak, és egy töröl körülbelül öt generációt ${ }^{89}$ tartott számon, a vagyon öröklése ezen belül történt. ${ }^{90}$ Egy törölt a billoghasználatról is meg lehetett ismerni, ugyanis a bélyeg elsődleges jele minden örxnek megegyezett, és a kiegészítő jelek a rokoni kapcsolatok természetét voltak hivatottak megmutatni. Ezek alapján a kiegészítő jelek hierarchikus párokat alkottak, amelyek lehettek testrészek (a 'körömágy' [jeter] és a 'farok' [sü̈l]; a 'szarv' [ewer] és a 'láb' [xöl] ${ }^{91}$ vagy égitestek ('nap' [nar] és a 'hold' [sar]), ${ }^{92}$ de úgy is jelezhették a leszármazást, hogy az elsődleges jelet vízszintesen tükrözték (burū ergesen ['balra/rossz irányba forgó']) vagy fejjel lefelé (dōšo xarsan ['lefelé néző']) elfordították. ${ }^{93}$ Egy billogon egyszerre két-három változtatás alkalmazható, és ez elég öt generáció jelölésére, ha a családokban átlagosan egy-két fiú örökös született. ${ }^{94}$ A rokonság közösen döntötte el, hogy egy családot alapító ifjú milyen módosításokkal használhatja a bélyeget, vagy hogy bizonyos esetekben kaphat-e újat. ${ }^{95}$ Tárkány említi, hogy hasonló jelváltoztatás a magyaroknál is ismert volt, ${ }^{96}$ és Szabadfalvi, valamint Paládi-Kovács is utal rá, hogy ismert olyan bélyegzővas, amely ilyen módon 2-300 év óta használatban van. ${ }^{97}$

\footnotetext{
87 Humphrey 1974: 476-477.

88 Elsődleges jelentése 'kereksátor-tetőgyürű négyzetes fedélnemeze', itt a másodlagos értelme használandó, vagyis 'háznép, család, hajlék'.

89 Ezen állítást rugalmasabban kell értelmezni. Többnyire azok számítottak bele a leszármazásba, akiknek fontos volt a rokonság (Humphrey 1974: 477-478).

90 Humphrey 1974: 477-478.

91 A jelek egymáshoz képest hierarchikus viszonyát az dönti el, hogy melyik helyezkedik el feljebb a testen.

92 Ebben az esetben a nap jele a rangosabb.

93 Humphrey 1974: 475-476; Ladjánszki 2018: 17-18.

94 Humphrey 1974: 481-482; Ladjánszki 2018: 20.

95 Ladjánszki 2018: 20.

96 Tárkány 1965: 390-391.

97 Szabadfalvi 1977: 249; Paládi-Kovács 2001: 636.
} 
A bélyegeket értelemszerüen a fiúutódok örökölték, ${ }^{98}$ és bár a nők is és a gyerekek is rendelkeztek saját állatállománnyal, ezek felett a családfö rendelkezett. ${ }^{99} \mathrm{~A}$ házasuló leányok kelengyéjébe (inj) beletartozott néhány jószág is, amelyet a menyasszony rokonsága biztosított, és ezeken az állatokon a leány apjának a tamgája szerepelt. A hozomány nagysága a töröl vagyonáról is árulkodott, és minél gazdagabb volt a menyasszony, annál valószínübbnek tünt, hogy tisztelettel bánik vele a férj és a családja. Humphrey leírása alapján, ha túl kevésnek bizonyult az asszonyi ménes, a férj a feleség hozzátartozóinak haragjától való félelem nélkül a jószágra sütötte a saját jelét, vagy titokban átbillogozta a feleség megelletett csikóit, ha azonban tekintélyes volt az állomány, akár át is vehette az asszonyi oldal bélyegét, ha a feleség lovai sikeresebben gyarapodtak a sajátjainál. ${ }^{100}$

Bayanbat szerint a billogjelek nyomon követése a mongol családfakutatásban is segítséget nyújthat. ${ }^{101}$ Síremlékkel temetkező kultúrákban (magyar, török és tatár törzsek egy része) gyakran találkozhatunk a sírkövekre, fejfákra vésett billogjellel. Magyarországon az ember a bélyegét egyéb vagyontárgyaiba, házának ajtajára is rányomta. Ha bélyege eléggé ismertté vált, akár síremlékén is feltüntették. A jelről mindenki pontosan tudta, kinek a sírhalma előtt áll, a tájékozódáshoz nem volt szükség az olvasás ismeretére. ${ }^{102}$ Baski tanulmányában - mint a Bevezetőben írtam - dobrudzsai és krími tatár és török sírok bélyegeit gyüjtötte össze, amelyeket kiegészített más népek - nogajok, kazakok, karakaplakok, kirgizek, türkmének, baskurtok, oguzok, bolgárok, mongolok, magyarok és a régen Észak-Mongólia területén élt türkök - jószágjeleivel is. Az általa felállított evolúciós lépcsőfokok közül a módosított jelek szintje az örökösödés és a rokonság folytán elváltoztatott jegyekre utal. A kettős jelek minden valószínűséggel a családokba beházasodott nők sírjai voltak. ${ }^{103}$

Fontos kiemelni, hogy az adatok alapján a fent felsorolt népeknél nagyon hasonló jelek és bélyegzési szokások hagyományozódtak tovább, és a jószágjegy törzsi, nemzetségi jelként való használata általánosnak volt mondható.

\footnotetext{
98 A billogvasat az elsőszülött fiú örökölte, az öccseinek új vagy módosított bélyeget kellett kapniuk (Humphrey 1974: 478; Ladjánszki 2018: 15).

99 Humphrey 1974: 477.

100 Humphrey 1974: 479.

101 Bayanbat 2016: 196.

102 Tárkány 1965: 389.

103 Baski 2003: 39-66.
} 
Tárkány szerint - hivatkozik rá Ladjánszky - lehetséges, hogy éppen a nemzetségi jelekből, az állatok háziasítása idején alakultak ki a tulajdonjegyek. ${ }^{104}$

\section{A billogozás folyamata}

Magyarországon a bélyegzést a tulajdonos, a bélyegzővasat készítő kovács vagy valamely hivatalos személy végezte. ${ }^{105}$ Paládi-Kovács szerint csak a fiatal, értékesebb lovakat kellett jelölni, ugyanis az öreg, igáslovakat nem lopták el a lótolvajok. ${ }^{106} \mathrm{~A}$ bélyegzés időpontja a magyar hagyományok szerint ünnepélyes keretek között, nagypénteken zajlott, ${ }^{107}$ és a tulajdonos terveitöl függött, hogy a lovat hány éves korában bélyegezték meg. Ez akkor történt meg, amikor a tulajdonos idegen jószágok közé, a ménesbe akarta ereszteni az egyedet. Ezt hívták a ló „első füre menésének”. A XVIII. század közepén Debrecenben fordítva történt a dolog: a csikókat a ménesben nevelték, és csak negyedfü korukban billogozták meg őket. A Dunántúlon, ahol kevesebb lehetőség nyílt a ridegtartásra, a lovak kocsiba fogása döntött a pontos napról. Tárkány adatai szerint májusban (amikor a lovak bogarazni kezdtek), György (április 24.) és Mihály (szeptember 29.) napján, augusztusban és ősszel egyaránt billogoztak az ország területén. ${ }^{108}$

A mongol szokások szerint az első ló bélyegzését a gazdának vagy a környéken tiszteletben álló, állatokhoz értő időskorú embernek kell elvégeznie. ${ }^{109}$ Megfigyeléseim alapján ezután bármelyik felnőtt férfi bélyegezhet, akinek van ebben gyakorlata. ${ }^{110}$ Évente kétszer billogoznak, tavasszal a másod- és harmadfü csikókat, ősszel az elsőfü csikókat jelölik. Vedlés elött (üs gūjix) kerítenek sort rá, mert az újranövő szőrben jól meglátszik a jel. ${ }^{111}$ Összel hideg időben, szeptember 15. és október 15. között billogoznak, hogy az égetett jel sebe ne fertőződjön el. ${ }^{112} \mathrm{Az}$ állatokkal kapcsolatos munkavégzéseket a mon-

\footnotetext{
104 Tárkány 1965: 194; Ladjánszki 2018: 9. n. 13.

105 Tárkány 1965: 388.

106 Paládi-Kovács 2001: 636.

107 Szabadfalvi 1977: 249; Tárkány 1965: 386.

108 Tárkány 1965: 386.

109 J̌ambaldorǰ 1996:150; Bán 2018: 16. n. 88.

110 Saját gyüjtés: 2017.09.24. Xentī aimag, Cenxermandal sum, Sügüt bag.

111 Bayanbat 2016: 203-204; Bán 2018: 16.

112 Jambaldorj̆ 1996: 145; Ladjánszki 2018:14. Meleg időben viszont lehet szőrbillogot égetni (J̌ambaldorǰ 1996: 145).
} 
gol hagyomány az asztrológus lámák által évröl évre összeállított lunáris kalendárium (bilgīn tōllīn kalendari) napjaihoz igazítja, amelyet a Gergelynaptárral (argīn tōllīn kalendari) párhuzamosan használnak. ${ }^{13}$ A holdnaptár jeles (öljìt ödör, sain ödör, beleg dembereltei ödör) és baljós napokra bontja az év holdhónapjait, és világosan meghatározza, milyen tevékenységet mikor kell végezni. Egy hónapban több, a tevékenységre alkalmas nap is lehet, ilyenkor a család döntheti el, mikor jó neki a munkavégzés. ${ }^{114}$ A szerencsés napok meghatározására a kalendáriumon belül több rendszer is létezik. ${ }^{115}$

A magyar források a bélyegzővassal kapcsolatban megemlítik, hogy a tulajdonos nagy becsben tartotta és őrizte otthonában. ${ }^{116} \mathrm{~A}$ mongol kultúrában a bélyegvasnak nagy szerepe volt, a jurta tiszteleti helyén, a férfi oldalon tartották. ${ }^{117}$ Pürewxü̈ közlése alapján a billogokat a lovakra felügyelő ail jurtájában őrzik, ugyanis - teszi hozzá - a billognak a lovak mellett kell maradnia. ${ }^{118}$ A billogozás napján tüzben megtisztítják (gald ariusgax) tejjel és fehér étellel felszentelik (sü cagān idēgēr myalāx), áldozati kendővel megkötik, felgöngyölik (xadgā ruyaǰ orōx). Csak a családfö viheti a billogozás helyszínére. Az eszköz nem érhet le a földre, ha lovon szállítják, nem köthetik a nyereg vérszíjaira, ezenkívül a földre dobni vagy rálépni sem szabad. A munka után a vasat tejben hütik (tamga soix 'a billogozóvas edzése'), és xadagban tárolják. A később eladásra szánt ló hosszúszőrét a nyélre ${ }^{119}$ kötik, hogy a háznál maradjon az állatban lakozó jószerencse. ${ }^{120}$

A mongol és a magyar pásztormüveltségben ideiglenes és állandó égetett tulajdonjegyekről egyaránt beszélhetünk, előbbinek számít a szőrbe égetett billog (üsen tamga) ${ }^{121}$ és maradandónak pedig a börbe égetett változat (maxan tamga, szó szerint 'húsbillog'), ${ }^{122}$ továbbá mindkét kultúrában ismert a jelenség, amikor a bélyeget valamilyen okból kifolyólag elhibázzák. A magyar hagyomány rontásnak nevezi, ha az égetett jegyet csalárd célból meg akarjuk

\footnotetext{
113 Adatközlő: D. Dawāxūü - lópásztor, Világosan Élenjáró Versenyedző (Tod Manlai Uyāč) címet viseli; Bán 2018: 11.

114 Bayanbat 2016: 200.

115 Erről bővebben lásd: Bán 2018.

116 Tárkány 1965: 389.

117 Bővebben lásd: Ladjánszky 2008b, különös tekintettel a cikkben található képi anyagra.

118 Adatközlő: X. Pürewxü - építészmérnök, lótulajdonos.

119 Vagy a jurtatartó kötélre (čagtag) kötik (Birtalan Ágnes szóbeli közlése alapján).

120 Tömörjaw-Xürelbātar 2017: 150.

121 Tárkány is utal hasonlóra (Tárkány 1965: 387).

122 Ladjánszky 2008a: 2; Bayanbat 2016: 198.
} 
változtatni. Ez történhet rásütéssel vagy átsütéssel. ${ }^{123}$ Hasonló esetek a mongol területeken is jelen lehettek, de a mongol források inkább a rossz technikával járó hibákat részletezik. 'Felszíni billog' (xörsön tamga) jön létre, ha szőrbillog készítésénél túl forró a bélyegzővas, és megsérti a hámréteget. 'Billog növekedésének' (tamganī ösölt) hívják, amikor a sütés miatt a jószág összehúzza magát félelmében, és a jel erre az összehúzott bőrre kerül, majdamikor az állatot elengedik, nyugalmi állapotba visszatérve a böre újra megfeszül, kitágul, és vele együtt megnő a jegy. A 'billog kettéhasad, kettétörik' (tamga xagalčix), amikor a sütés pillanatában elcsúszik a bőrön, és eltorzítja a mintát. Az ilyen égetés nyomán (legtöbbször a túl forró billogvas vagy túlságosan erős nyomás miatt) forradásos seb keletkezik, és a minta nagy lesz. ${ }^{124}$

A billogozás módjait tárgyalva Tárkány először Ecsedi Istvánt idézi, aki azt írja le, milyen technikákkal fogják le, és bélyegzik a csikót:

„Bilyogozáskor nem kötözik meg a csikót, hanem felfíkezik és ennélfogva szorosan a szekér lőcsfühöz kötik, midőn egy hosszú rúd, vagy vendégoldal segélyével két ember a csikót a szekér oldalhoz szorítja, a gazda hirtelen farához nyomja a kemencében szalma pernyével megtüzesedett bilyogvasat." ${ }^{125}$

Ezután Nagy-Czirok Lászlóra hivatkozik, aki egy csikó ledöntését dokumentálta:

„A döntésnél a hátulsó bal lábra, csűdön felül egy hosszabb kötéllel hurkot vetettek, majd a kötéllel az állat jobb lábát a bal lábához húzták, a kötelet a hasa alatt az első két lába között elöre húzták, s a ló vagy marha nyakára kötött, rövid kötélen át a másik kötelet a hasa alatt ismét hátravezették a lába között. Mikor a kötél végét meghúzták, az állat feje és nyaka lefelé és hátrafelé, hátsó lábai meg előre húzódtak. Mikor így a jószág négy lába már majdnem összeért, nem tudott megállni a lábain, hanem eldőlt." ${ }^{126}$

Az állat ledöntése a mongolok körében is alkalmazott eljárásnak számít, jómagam csak ezt a módszert láttam 2014-es és 2017-es terepmunkáim során. Továbbiakban az általam megfigyelt bélyegzések menetét közlöm. ${ }^{127}$ Cikkében

\footnotetext{
123 Tárkány 1965: 389.

124 Bayanbat 2016: 200.

125 Ecsedi 1914: 249; Tárkány 1965: 385.

${ }^{126}$ Nagy-Czirok 1959: 94; Tárkány 1965: 385.

127 Lásd bővebben: Bán 2018: 16-19.
} 
és szakdolgozatában Ladjánszky is leírta a sütés módszerét, a tapasztalataim az ő állításainak nem mondanak ellent. ${ }^{128} \mathrm{Az}$ általam leírtakban említett szertartásos tevékenységek a jószág ártalmaktól való védelmét, a ménes szaporulatának a növekedését voltak hivatottak elősegíteni. ${ }^{129}$

A 2014-es bélyegzés a következőképpen történt: egy esküvőn vendégeskedtem, és a szertartások után, a lakoma alatt a férfiak egy csoportja kiment az akolhoz (xašā vagy jüčê). Két férfi belépett a lovak közé, és lasszóval (buguil, calam) kifogott egy fiatalabb csikót. Elöször a karámon belül fülénél megragadva és farkánál fogva döntötték le (unagax), megigazították a lasszót, majd kivonták a kerítésen túlra a nézök közelébe, és újra ledöntötték a jobb oldalára. Az egyik férfi az állat lapockájára és a nyaka tövére ült, a fejét a pofájánál fogva megtartotta, hogy ne mozogjon. A másik a háta felől közelítette meg, fara bal oldalán ollóval (xaič) szőrt vágott le egy területen (ilyenkor már tömött, téli ször borította a lovakat). Egy harmadik, díszes köntöst (dēl) viselö férfi, valószínüleg a gazda, a felhevített billogozóvassal (tamga) rásütötte a tulajdonjegyét. A vasat ezután tejben hütötték. A tejjel meghintették a ló homlokát, majd ott helyben elengedték. A tejből minden jelenlevő ivott egy kortyot. Külön ezért az alkalomért végzett buddhista szertartást nem dokumentáltam, de az esküvőn történt szútraolvasás. ${ }^{130}$

A következő billogozás 2017. szeptember 24-én folyt, amelyet X. Pürewxü lótulajdonos és felesége vendégeként szemlélhettem meg. Pürewxü Ulánbátorban lakó építészmérnök, de szülöhelye Xentī aimagban van, bátyja és apja most is ott él. A Xentī aimagban élő rokonok lópásztorok, és gondozzák Pürewxū ménesét, a magukéival együtt tartják. Pürewxü, mint minden városban élő jószágtulajdonos, az állatokkal kapcsolatos idénymunkák alkalmával elutazik vidékre, és kiveszi a részét a feladatokból. A billogozásra összeterelt ménes 300 egyedet számlált, négy ail lovát fogta össze.

A billogozóvasakat egy kint felállított tüzhelyen hevítették. A hagyományos bélyegzési mód mellett fagyasztást is alkalmaztak. Közben a már elöre körkarámba (dügreg xašā) terelt lovakból botospányvával (ürga) kifogták a jószágokat, ledöntötték, és megpipázták (corowdox) öket. Miután elökészültek, megkezdődött a buddhista szertartás, füstáldozat bemutatása (san tawix), amelyet két láma végzett. Az egyik láma a szertartás egyik pontján egy inget ${ }^{131}$ (camc)

\footnotetext{
${ }^{128}$ Ladjánszky 2008a; Ladjánszki 2018: 13-14.

129 Lásd bővebben: Bán 2018: 8-10.

130 Saját gyüjtés. 2014.10.10. Bulgan aimag, Büregxangai sum.

131 A szertartásból és az interjúkból nem derült ki, hogy az ing kihez tartozik.
} 
tartott a kezében. Szútraolvasás közben a karám körül libációt mutatott be a házigazda. Megkezdődött a billogozás, mialatt egy idősebb nő is - feltehetően a házigazda felesége - tejjel végzett szóróáldozatot mutatott be ugyanazon az útvonalon. Ugyanígy az egyik láma magokat hintve a karám felé áldozott. Majd egymás után két asszony - egyik Pürwxü felesége volt, a másik asszonyt nem ismertem fel - kerülte meg (toirox) a karámot, mindkettejük egy-egy füstölöt (boipor) tartott a kezében.

Ezalatt folyt a billogozás. A ledöntött lovak farának bal oldalát egy flakon szappanos vízzel lelocsolták, és leborotválták a megfelelő részen, majd rásütötték a fagyasztásos vagy a hagyományos billogot (mindkettőre a példát lásd: Függelék: II. a, b és III. a, b., c kép). Pürewxü elmondta, hogy az elsőfü csikókra (unaga) fagyasztásos billog, a kancákra, amelyeket az előző billogozás óta vettek, hagyományos billog kerül. Állítása szerint a fagyasztásos billoggal nehezebben fertőződik el a seb, ezért sütik vele a fiatalabbakat. Fél év múlva a helyén fehér szőr nő ki. ${ }^{132}$

A billogozást nők és gyermekek is segítették. Apró feladatokat végeztek: újratöltötték a flakonokat, tartották az eszközöket, hordták a jurta mögött vágott fát, szították a tüzet. Bár a lovakkal hagyományosan férfiak dolgoznak, Pürewxü szerint a nők és a gyermekek részvétele régen sem volt tabu (cēr). A lovak körüli munka azért férfimunka, mert férfierőt igényel. ${ }^{133}$ A vendéglátó család női tagjai az ételért voltak felelősek. A vendégváró asztal fehér ételekkel (cagān idē), kumisszal (airag), tejjel, vodkával (arxi) volt megterítve. A munkások és a vendégek folyamatosan betértek egy kis pihenőre. A nők később az ebédet készítették.

Miután végeztek az összes munkával, mindenki helyet foglalt a jurtában. Kumiszban hütötték az utolsó billogozóvasat, majd kivették, és lecsöpögő italból sorban mindenki kapott néhány cseppet a tenyerére, és megitta. Ha kellett, újra és újra megmerítették. Ezután a házigazda bekente fehér étellel az utolsó vas jelölő végét, és elrakta a többi közé. Pürewxü mindegyik vasnak pénzt áldozott, majd adott a munkásoknak is köszönetképpen. Ezután a távol élők hazamentek, a helyiek ünnepeltek (nairlax). ${ }^{134}$

\footnotetext{
132 Adatközlő: X. Pürewxü - építészmérnök, lótulajdonos.

133 Adatközlő: X. Pürewxü - építészmérnök, lótulajdonos.

134 Xentī aimag, Cenxermandal sum, Sügüt bag.
} 


\section{Összegzés}

Jelen tanulmány célja a magyar és mongol lovas billogozási szokások és jellemzők ismertetése és összehasonlítása volt, továbbá a kutatásba igyekezett újabb eredményeket is bevonni. Hagyományosan a nagyállattartó pásztorkodás kívánta meg a billogok használatát és számontartását. Új bélyeg alkotása és használata egy bizonyos szintig a helyi közösség engedélyétől és elismerésétől függött, az állami ellenőrzés szigorodásával (Magyarországon a XVI-XVIII. századtól, Mongóliában a XVIII-XIX. századtól) azonban törvényekkel, rendeletekkel szabályozták a folyamatot. A két kultúrában a billogozás más-más funkciója került érvényre. Magyarországon a bélyeg elsődlegesen jogi jelként, peres viták eldöntésére szolgáló bizonyítékként volt fontos, Mongóliában pedig a hagyomány, a leszármazás részét képezte, továbbá nem elhanyagolható szerencsehozó és védelmi szerepet játszott a jószág életében. Természetesen Magyarországon is láthattunk példát arra, hogy a családi jelet kis változtatásokkal az utódok is tovább használták, és Mongóliában a bélyeg természetéből adódóan jogi tartalmat is képviselt. Ezenkívül elmondható, hogy mongol billogozási folyamatban a szertartások jelentősége nagyobb, mint a magyarban.

Magyarországon az adminisztratív, jogi célok és a tenyésztési nyilvántartás miatt egy lóra több billog is kerülhet, amelyek a tulajdonjegy kisegító jeleiként funkcionálnak, és önálló jelentéssel bírnak. Mongóliában általában egy bélyeg látható a lovakon, és kiegészítő jeleik a tulajdonos családban elfoglalt hierarchikus helyét szimbolizálják, sőt kiegészítő jelnek számított az is, hogy az elsődleges jelet elforgatták.

\section{Függelék}

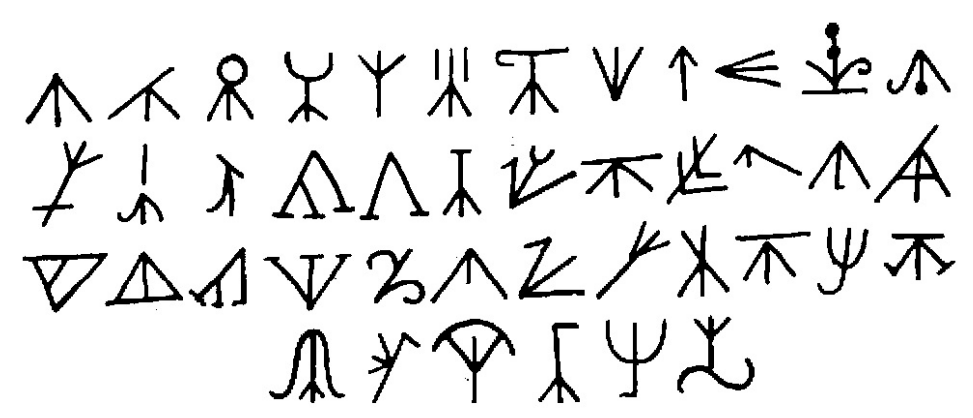

I. kép. Magyarországon gyüjtött Daruláb jegyek 

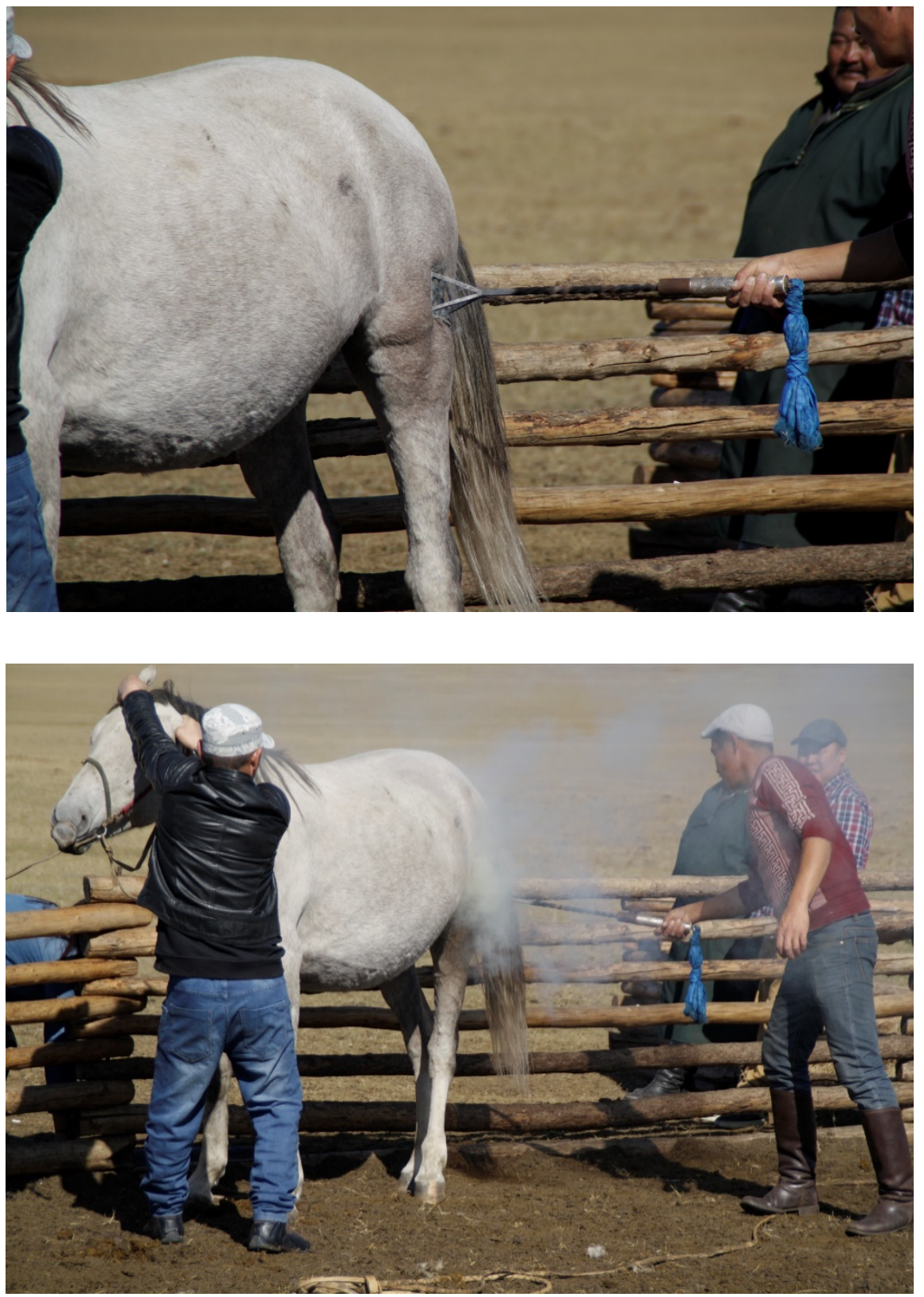

II. a, b kép. Hagyományos bélyeg sütése a ló bal oldalára 




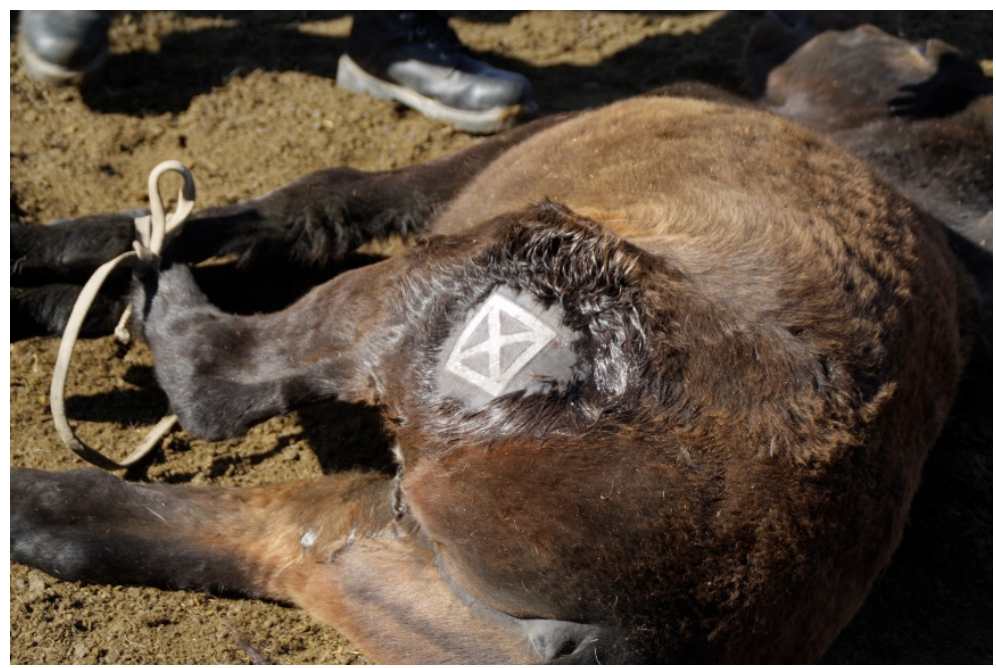

III. a, b, c kép. A fagyasztásos bélyegzés elökészitése és a sütés folyamata

\section{Terepmunkaadatok}

2014.10.10. Bulgan aimag, Büregxangai sum.

2017.09.24. Xentī aimag, Cenxermandal sum, Sügüt bag.

Interjúk:

X. Pürewxü, halha férfi (borǰigin), 43 éves, építészmérnök, lótulajdonos. Hely: Xentī aimag, Cenxermandal sum, Sügüt bag. Idő: 2017. 09. 24.

X. Pürewxü, halha férfi (borjigin), 43 éves, építészmérnök, lótulajdonos. Hely: Ulānbātar.

Idő: 2017. 11. 12.

D. Dawāxū, nemzetsége ismeretlen, férfi, 67 éves, lópásztor, a Világosan Élenjáró Versenyedzö (Tod Manlai Uyāč) címet viseli.

Hely: Ulānbātar.

Idő: 2018. 01. 24. 


\section{Felhasznált másodlagos szakirodalom:}

Avar Ákos 2008. „A jószág színe.” In: Birtalan Ágnes (szerk.): Material Culture. (Traditional Mongolian Culture I.). Materielle Kultur. (Traditionelle mongolische Kultur I.). A mongol nomádok anyagi müveltsége. (Hagyományos mongol müveltség I.). Ulamjlalt mongol soyol. Wien-Budapest: IVA-ICRA Verlag - ELTE Belső-ázsiai Tanszék (DVD).

Badamxatan, S. - Cerenxand, G. 2012. Mongol ulsīn ugsātnī jüi I-III. [Mongólia néprajza] Ulānbātar: Monsudar.

Bán Kornélia 2018. A lovas munkák vizsgálata és változásai a 21. századi Mongóliában. (MA-szakd., Eötvös Loránd Tudományegyetem).

Baski Imre, 2003. „Tamgas and Names (A Contributiontothe Tatar Ethnogenesis).” In: Tàtarii în istorie şi în lume. [Tatárok a történelemben és a világban.] Bucuresti: Editura Kriterion, 39-66. (2. kiadás).

Bayanbat, D. 2016. Mongol adūnī newterxī toli I-II. [Mongol lovas enciklopédia] Ulānbātar: Mönxīn üseg.

Birtalan Ágnes 1996. „Obó hagyományok a mai Mongóliában.” In: Birtalan Ágnes (szerk.) Tanulmányok a mongol népi hiedelemvilágról [Öseink nyomán Belső-Ázsiában 1.] Budapest: Nemzeti Tankönyvkiadó, 4-20.

Birtalan Ágnes, Tamga. (kézirat).

Birtalan Ágnes: 2008. „A jószág korbeosztása és egyéb a jószág neméhez, viselkedéséhez kapcsolódó kifejezések.” In: Birtalan Ágnes (szerk.) Material Culture. (Traditional Mongolian Culture I.). Materielle Kultur. (Traditionelle mongolische Kultur I.). A mongol nomádok anyagi müveltsége. (Hagyományos mongol müveltség I.). Ulamjlalt mongol soyol. Wien-Budapest: IVA-ICRA Verlag - ELTE Belső-ázsiai Tanszék (DVD).

Cewēndoř̆, D. 1999. Mongolīn ertnī urlagīn tüxx. [Mongólia korai müvészettörténete] Ulānbātar: Mongol Ulsīn Šinj̆lex Uxānī Akademīn Tüxxīn Xürēlen.

Clauson, Gerard 1972. An Etymological Dictionary of Pre-Thirteenth-Century Turkish. Oxford: Clarendon Press, 340, 504-505.

Dörfer, Gerhard 1965. Türkische und Mongolische Elementeim Neupersischen II. Wiesbaden: Franz Steiner Verlag GMBH, 418-420, 554-565.

Ecsedi István 1914. A Hortobágy puszta és élete. Debrecen: Debreczen Szab. Kir. Város Könyvnyomda-vállalata.

Humphrey, W. Caroline 1974. „Horse Brands of theMongolians: A System of Signs in a Nomadic Culture." American Ethnologist 1: 471-488.

J̌ambaldorj, C. 1996. Morin erdene. [Lódrágakő] Ulānbātar: s.n.

Kiss Lajos - Papp László (szerk.) 1984. A magyar nyelv történeti-etimológiai szótára I. Budapest: Akadémiai Kiadó, 277.

Kun Péter 2003. Szelek szárnyán. A sztyeppei nomádok lovaskultúrája. Debrecen: Arkadas Kiadó.

Ladjánszki Endre 2018. A mongol nomádok jószágtulajdon-jelölései és történeti hátterük. (MA-szakd., Eötvös Loránd Tudományegyetem).

Ladjánszky Endre, 2008a. „A mongol nomádok jószágtulajdon-jelölései.” In: Birtalan Ágnes (szerk.) Material Culture. (Traditional Mongolian Culture I.). Materielle Kultur. 
(Traditionelle mongolische Kultur I.). A mongol nomádok anyagi müveltsége. (Hagyományos mongol müveltség I.). Ulamjlalt mongol soyol. Wien-Budapest: IVA-ICRA Verlag - ELTE Belső-ázsiai Tanszék (DVD).

Ladjánszky Endre, 2008b. „Tulajdonjegyek.” In: Birtalan Ágnes (szerk.): Material Culture. (Traditional Mongolian Culture I.). Materielle Kultur. (Traditionelle mongolische Kultur I.). A mongol nomádok anyagi müveltsége. (Hagyományos mongol müveltség I.). Ulamjlalt mongol soyol. Wien - Budapest: IVA-ICRA Verlag - ELTE Belső-ázsiai Tanszék (DVD).

Nagy-Czirok László 1959. Pásztorélet a Kiskunságon. Budapest: Gondolat Kiadó.

Paládi-Kovács Attila 2001. „A lovak számon tartása, tulajdonjegyek.” In: Paládi-Kovács Attila (szerk.) Gazdálkodás. Magyar Néprajz II. Budapest: Akadémiai Kiadó, 635-636. (Internetes elérés: http://mek.niif.hu/02100/02152/html/02/307.html).

Paládi-Kovács Attila 1993. „Nyájak és pásztorok.” In: Paládi-Kovács Attila (szerk.) $A$ magyar állattartó kultúra korszakai. Kapcsolatok, változások és történeti rétegek a 19. század elejéig. Budapest: MTA Néprajzi Kutatóintézet, 121-132, 205-217, 302-319.

Paládi-Kovács Attila 1997. „A magyar lótartás jellege a honfoglalás korában.” In: Kovács László - Paládi-Kovács Attila (szerk.) Honfoglalás és néprajz. [A honfolgalásról sok szemmel 4.] Budapest: Balassi Kiadó, 95-109.

Perlē, X., 1975. Mongol tümnī garlīg tamgār xaiǰ sudlax ni. [A mongol nép eredetének kutatása a billogjeleken keresztül] Ulānbātar: BNMAU-īn Šinǰlex Uxānī Akademīn Tüxīn Xürēlen.

Szabadfalvi József 1977. „Bélyeg, billog.” In: Ortutay Gyula (szerk.) Magyar Néprajzi Lexikon I. Budapest: Akadémiai Kiadó, 249-250.

Szajkó István et al. 2009. A lovak tenyésztése, takarmányozása és betegségei. s. 1.: FVM VKSZI. (CD, oktatási segédanyag).

Szenti Tibor - Bicsérdy Gyula 1998. Állatjelölések. Hódmezővásárhely: DATE Mezőgazdasági Főiskolai Kar.

Tárkány Szücs Ernő 1965. „A jószágok égetett tulajdonjegyei Magyarországon I-II.” Ethnografia 76: 187-199, 359-410.

Tárkány Szűcs Ernő 1977. „Jószágjegy, jegy.” In: Ortutay Gyula (szerk.) Magyar Néprajzi Lexikon II. Budapest: Akadémiai Kiadó, 687-688. (Internetes elérés: http://mek.niif.hu/ 02100/02115/html/2-1705.html).

Tárkány Szücs Ernő 1982. „Tulajdonjegy, birtokjegy.” In: Ortutay Gyula (szerk.) Magyar Néprajzi Lexikon V. Budapest: Akadémiai Kiadó, 360-362. (Internetes elérés: http:// mek.niif.hu/02100/02115/html/5-847.html).

Tömörǰaw, M. - Xürelbātar, N. 2017. Mongol malčnī erdem uxānī dēj oršwoi. [A mongol pászortudomány legjavából]. s. 1.: TEPE.

Žamcarano, Cyben Ž. 1959. „Qalq-a J̌irum”. [Halha Törvénykönyv] In: Studia Mongolica 1: 1-69. 


\section{Képek forrása:}

I. kép: Tárkány Szücs Ernő 1965. „A jószágok égetett tulajdonjegyei Magyarországon II.” Ethnografia 76: 396.

II. a., b. kép. Saját gyűjtés. 2017.09.24. Xentī aimag, Cenxermandal sum, Sügūt bag.

III. a., b., c. kép. Saját gyüjtés. 2017.09.24. Xentī aimag, Cenxermandal sum, Sügüt bag. 